УДК 378.011.3-057.87:[37.013:005.336.5]

UDC 378.011.3-057.87:[37.013:005.336.5]

DOI: $10.31475 /$ ped.dys.2020.29.03

ОКСАНА ВОЛОШИНА,

кандидат педагогічних наук, доцент (Украӥна, Віннищя, Віннищький державний педагогічний університет ілені Михайла Коцюбинського, вул. Острозького, 32)

OKSANA VOLOSHINA,

Candidate of Pedagogical Sciences, Associate Professor (Ukraine, Vinnytsia, Vinnytsia Mykhailo Kotsiubynskyi State Pedagogical University,

Ostrozkoho St., 32)

ORCID: 0000-0002-9977-7682

\title{
Компонентна структура, критерії сформованості професійної майстерності майбутніх педагогів
}

\section{Component Structure, Criteria of Formation of Professional Skills of the Future Teachers}

У статті порушено проблелу виокреллення колпонентної структури, визначення критерїв сбборлованості профбесійной майстерності майбутніх педагогів. Для виокреллення колпонентної структури сбборлованості проббесійної майстерності майбутніх педагогів визначено фбункиї профбесійної діяльності сучасного вчителя, шо реалізуються в иілісній структурі особистісної колпетентності, а сале периептивну, адаптивну, координаційну, ребблексивну фбункиї. Розкрито профбесійно-значущі особистісні якості педагога, які розглядаєло як колпоненти здатності педагога до профбесійної майстерності: елпатія (сприяє реалізаиї перцептивної ббнкиї), салоконтроль (основа для реалізацї адаптивної фбункиї̈), організаторські здібності (сприяе реалізаціӥ координаційної ббункиї) $і$ ребблексія (є основою для реалізаціӥ рефблексивної бункиї). Охарактеризовано критерії визначення рівня сбборлованості педагогічної майстерності: мотиваційний; когнітивний; ббункиіональний.

Ключові слова: фбункиї профбесійної діяльності педагога; педагогічна лайстерність; колпонентна структура профбесійної майстерності педагога; критеріӥ визначення профбесійної миайстерності педагога.

The article raises the problem of distinguishing the component structure, determining the criteria, levels of professional skills of the future teachers. To distinguish the component structure of the conformation of professional skills of the future teachers the functions of professional activity of modern teachers have been identified, which are implemented in a holistic structure of personal competence, namely perceptual, adaptive, coordination, reflexive functions. The functions of the future teacher's ability to professional skills identified by us correspond to the professionally significant teacher's personal qualities, which we consider as components of the teacher's ability to professional skills, especially empathy (promotes the implementation of the perceptual function), self-control (the basis for the implementation of the adaptive function), organizational skills (promote the implementation of the coordination function) and reflection (the basis for the implementation of the reflexive function). The criteria for determining the level of formation of pedagogical skills have been identified: motivational (reflects the readiness to form professional pedagogical competence; the desire to obtain special knowledge and the formation of the necessary practical skills); cognitive (involves the possession of professionally significant knowledge: special, psychological, managerial, scientific and methodological, domain, technological, knowledge of the sociocultural context); functional (aimed at developing skills to master the technologies of professional functions); social (aimed at optimizing human resources). Three levels of formation of pedagogical skill of the future teachers have been described: sufficient, average, high.

Key words: professional teacher's engagement, component structure of teacher's professional skill, criteria of teacher's professional skill, levels of conformation of teacher's professional skill.

Вступ/Introduction. Актуальність дослідження визначається якісними змінами в системі вищої педагогічної освіти, пов'язаними 3 необхідністю підготовки компетентних педагогів відповідно до впровадження концепції Нової української школи.

Інноваційні процеси в освіті свідчать, що високий рівень знань з предмета та володіння 
методикою його викладання вже не можуть повністю характеризувати рівень професійної підготовки вчителя. Аналіз практики доводить, що однією з серйозних проблем сучасної освітньої системи $е$ недостатній рівень підготовленості педагогів до роботи в умовах, які вимагають самостійного прийняття оптимальних педагогічних рішень. Практично орієнтовані компетентності вчителя самостійно, науково обгрунтовано конструювати освітній процес формуються спонтанно після навчання в університеті або утворюються досить довго.

Випереджаючий розвиток педагогічної освіти обумовлюе необхідність оріентуватися на формування і вдосконалення педагогічної майстерності, що передбачае, крім знань, формування здатності до творчості і саморозвитку майбутнього вчителя. Професійна діяльність більшості вчителів насичена стереотипами і методичними штампами. Необхідна систематична спеціальна робота з формування і розвитку у майбутніх вчителів педагогічної майстерності.

Мета / Aim. Мета статті - виокремити компонентну структуру сформованості професійної майстерності майбутніх педагогів.

Методи / Methods. Для досягнення поставленої мети дослідження було використано комплекс взаємопов'язаних методів дослідження - аналіз, синтез, узагальнення результатів наукових пошуків в літературних джерелах та аналіз науково-методичної літератури.

Результати / Results. Для виокремлення компонентної структури сформованості професійної майстерності майбутніх педагогів нами визначено функції професійної діяльності сучасного вчителя (перцептивну, адаптивну, організаторську, рефлесивну), які реалізуються в цілісній структурі особистісної компетентності. Розглянемо їх більш детально.

Перцептивна фбункція здатності майбутнього педагога до педагогічної майстерності спрямована на адекватне сприйняття суб'єктами освітнього процесу один одного, на встановлення взаєморозуміння i, як наслідок, на забезпечення ефективної взаємодії між учасниками освітнього процесу.

На думку О. Єфремова, саме перцептивні навички проявляються в умінні розуміти в процесі комунікації вербальну і невербальну поведінку партнера; дозволяють адекватно сприймати людину, не приписувати їй певних властивостей. У процесі взаємодії пізнання людей передбачає як безпосередне сприйняття іншої людини, так і опосередковане її сприйняття через ії діяльність, через діяльність її групи. Група виступае і суб'єктом діяльності, і суб'єктом сприйняття. Групова діяльність включаеться в опосередкування всіх форм соціальної перцепції як найважливішої і необхідної змінної» (Єфремов О., 2010).

Враховуючи специфіку педагогічної діяльності, зазначимо, що у педагога має бути розвинена потреба в усвідомленні ставлення до себе учня (що е неможливим при недостатній розвиненості здатності до перцепції). В іншому випадку вчитель буде «...потенційно готовий орієнтуватися тільки на себе і свої егоцентричні цілі, оскільки внутрішньо ігноруе учня як суб’екта», сам же педагог у цьому випадку стане «приводним ременем для передачі знань» (Роджерс К., 1994).

Адаптивна фбункція проявляється в тому, що у вчителя з'являється необхідність у постійному самовдосконаленні; а це сприяе його професійному зростанню і творчій реалізації.

Взаемодія учасників освітнього процесу безпосередньо впливае на формування життевих планів і самореалізацію суб'єктів освітнього процесу. Саме в такій взаємодії «передаються норми культури і розвиваються культурні інтереси, що, безумовно, впливає на формування особистості». М. Громкова розглядае адаптивність як критерій дорослості, який характеризуеться наявністю у суб'єкта освітнього процесу певних комунікативних навичок міжособистісної взаемодії, а саме: вміння домовлятися, уникати конфліктів і вміння порозумітися (Громкова М., 2003).

3 іншого боку, прояв адаптивної функції можливий у вигляді виконання педагогом соціальних вимог, норм, прагнення відповідати очікуванням адміністрації, тобто приймати, перш за все, вимоги зовнішнього середовища. Можливий інший прояв адаптивної функції, який може призвести до спроб підпорядкувати оточуючих суб’ектів освітнього процесу (учнів, батьків учнів) цілям, вимогам і інтересам вчителя. Протистояти негативним проявам адаптивної функції може самоконтроль.

За допомогою зусиль щодо коригування своїх особистісних характеристик, уявлень і поведінки (тобто за наявності у майбутнього педагога самоконтролю і за умови відповідального ставлення до себе, свого майбутнього, i, отже, до професійної діяльності) людина намагається не тільки пристосуватися до свого партнера, а й стати для цієї групи «значущою особистістю. М. Сарджвеладзе довів, що адаптивна активність особистості мае спрямованість не тільки на зовнішне, соціальне оточення, а й на власниій внутрішній стан (робота над власним характером). Людина працюе над самоперетворенням, змінами, прагне до внутрішньої і зовнішньої адаптації; прагне не тільки відповідати вимогам соціуму, а й «виправдати довіру перед собою, узгодити власну лінію поведінки системі вимог до себе», що можливо тільки за наявності у вчителя такої особистісної якості як самоконтроль (Сарджеваладзе М., 1989). 
Координаційна фбункція здатності педагога до міжособистісної взаємодії проявляеться в тому, що вчитель організовуе як діяльність учнівського колективу, так і власну як суб'ектів педагогічної діяльності. Для досягнення високої ефективності координаційної діяльності колективу учитель повинен звертати увагу на власний емоційний стан, ставити себе на місце іншої людини (володіти «організаційною проникливістю»), бути енергійним керівником колективу, спрямовувати діяльність в необхідне русло.

Реалізація координаційної функції дозволяе зацікавити учнів, оскільки вчитель у процесі роботи впливає на розвиток особистісних якостей учнів стимулюванням їх мотиваційної сфери, на навчально-пізнавальну активність школярів, морально-естетичну складову, розвиток творчих здібностей та задатків, сприяе утвердженню гідності учнів у процесі міжособистісного спілкування.

Педагог повинен виявляти готовність до організаторської діяльності з усіма суб'ектами освітнього процесу, оскільки тільки при врахуванні інтересів усіх зацікавлених сторін (учнів, колег, батьків, адміністрації) можливе створення сприятливих зовнішніх і внутрішніх умов для ефективної діяльності всіх суб'ектів освітнього процесу.

Як зазначае I. Харламов, координаційна фрункція обумовлена тим, що при спільній роботі у вчителів виникае необхідність в «...узгодженні їх педагогічних зусиль щодо навчання і виховання учнів, координації їх діяльності та здійснення единого підходу до дітей. Подібну роботу необхідно також проводити з батьками учнів; залучати їх до спільної зі школою виховної діяльності» (Харламов I., 2004).

Ребблексивна фбункиія виявляється в прагненні адекватно сприймати і оцінювати свої взаемини з суб'єктами освітнього процесу, в спрямованості на пізнання свого внутрішнього світу і самовдосконалення, ретельному аналізі результатів власних дій в минулому і сьогоденні, прагненні сформувати цілісне уявлення про зміст своєї професійної діяльності.

Для реалізації цієї фрункції необхідна рефлексія, що передбачає, по-перше, спрямованість свідомості людини на себе і на розуміння власних психічних станів; по-друге, аналіз власних переживань і почуттів, роздумів над власним досвідом, вчинками.

У соціальній психології рефлексію визначають як здатність сприймати і оцінювати основні параметри своїх взаємин з іншими членами групи, а під перцепцією розуміють здатність сприймати і оцінювати основні параметри міжособистісних взаемовідносин інших членів групи. Я. Коломінський прийшов до висновку про те, що «...йдеться не стільки про два різних процеси, скільки про єдину перцептивно-рефрлексивну діяльність» (Коломінський Я., 2010).

Виявлені функції здатності майбутнього педагога до професійної діяльності відповідають професійно-значущим особистісним якостям педагога, які ми розглядаемо як компоненти педагогічної майстерності майбутнього вчителя, а саме: емпатія, самоконтроль, організаторські здібності і рефлексія. Розглянемо структурні компоненти досліджуваної нами здатності більш докладно.

Emnamiя - одна з основних особистісних якостей, яку розглядаємо як структурний компонент здатності вчителя до прояву педагогічної майстерності. Емпатія сприяе реалізації перцептивної функції. Педагог отримуе можливість в повній мірі звернутися до власного «Я», виявити свої здібності i, як наслідок, ефективно взаемодіяти з учасниками освітнього процесу. Саме емпатія сприяе міжособистісній взаемодії суб'єктів освітнього процесу, виявляється в ставленні педагога до учнів, співпереживанні й співчутті під час виникнення у них труднощів; спонукає вчителя в разі необхідності допомагати іншим суб'єктам освітнього процесу.

Педагог, який не спроможний ставитися до учнів з розумінням, учитель, який не володіе такою особистісною якістю як емпатія, не здатний адекватно сприймати почуття розгубленості або страху, які інколи виникають у школярів. Саме завдяки емпатії педагог отримуе можливість плідно взаемодіяти, жити у злагоді як з навколишнім соціумом (учнями, колегами, батьківським колективом), так і з самим собою.

Емпатія проявляеться в оріентації на загальнолюдські цінності; виявляеться у педагогічній спостережливісті і в прагненні до пізнання іншого. Ознакою емпатії $е$ і те, що вчитель завжди прагне проаналізувати, усвідомити сприйняття і ставлення до себе учасників освітнього процесу (учнів, батьківського колективу, колег), оскільки без цього неможливо порозумітися з іншими i, як наслідок, ефективно взаємодіяти.

Салоконтроль як структурний компонент професійної майстерності майбутнього педагога, $е$ основою для реалізації адаптивної функції. Саме самоконтроль сприяе успішній адаптації людини до навколишнього соціального середовища, яка залежить від низки факторів: емоційного стану особистості, рівня самоконтролю, від того, як людина оцінюе ситуацію, наскільки відповідально підходить до вирішення поставлених завдань, втілення в життя поставлених перед собою цілей. До ознак самоконтролю слід віднести: володіння педагогом навичками емоційної саморегуляції, прояв комунікативної гнучкості, прагнення до співпраці і постійної самоосвіти. 
Організаторські вління е основою для реалізації координаційної функції здатності майбутнього вчителя до міжособистісної взаемодії у професійній діяльності. Цей структурний компонент, перш за все, дозволяе вчителю раціонально організувати як власну діяльність, так i навчальну діяльність суб’єктів освітнього процесу, навчити учнів працювати в команді.

Сучасний педагог повинен володіти вмінням вести учнів за собою, заохочувати їх до різноманітної діяльності з метою підвищення результативності навчання; вміти зацікавити своєю навчальною дисципліною, правильно розподіляти час, координувати діяльність суб'ектів освітнього процесу. Саме організаторські здібності сприяють організації діяльності колективу педагогом, сприяють перетворенню колективу з об'єкта в суб'єкт освітнього процесу.

До ознак сформованості організаторських здібностей відносяться: вміння координувати зусилля учасників освітнього процесу, раціональна організації власної професійної діяльності.

Ребблексія є основою для реалізації рефлексивної функції, здатності майбутнього вчителя до міжособистісної взаємодії в професійної діяльності. Професійно-особистісна рефлексія педагога визначається його очікуваннями і вимогами до себе як професіонала. Саме рефлексія забезпечуе сприймання педагогічної реальності об'єктивно, дає можливість пізнавати свій внутрішній стан, порівнювати себе в минулому і в сьогоденні з метою аналізу і корекції власної діяльності, прагнення до самоосвіти та самовдосконалення.

Обговорення / Discussion. Н. Джига, характеризуючи особистісну редлексію, зауважуе, що процес осмислення власних вчинків призводить, поруч зі зміною ставлення суб'екта до власного «Я» (проявляеться у вигляді вчинків), до зміни ставлення до знань і вмінь. Таким чином, рефлексія розглядається як умова самовдосконалення студента i формування ставлення до освітнього процесу як процесу управління - співуправління - самоврядування, що призводить суб’єкта освітнього процесу до усвідомлення свого особистісного права на зміну запропонованої моделі навчання, поведінки або діяльності з урахуванням особливостей навчальної ситуації (Джига Н., 2009).

Завдяки здатності до рефлексії майбутні педагоги в умовах особистісно-оріентованої педагогічної тріади «управління - співуправління - самоврядування» з об’єкта (при управлінні освітнім процесом) перетворюються в об’єкти і суб’екти при співуправлінні і стають суб'ектами (в процесі самоврядування) з метою самозміни, вдосконалення та розвитку (Джига Н., 2009).

Педагогу необхідно володіти рефлексивної культурою (утримуватися від жорсткої алгоритмізації власної діяльності, самому контролювати процес саморозвитку). Усвідомлюючи причини і наслідки власних дій, при вирішенні педагогічних ситуацій викладач педагогічного закладу вищої освіти сприяе формуванню рефлексії як складової педагогічної майстерності майбутнього педагога.

3 рефлексією вчителя пов'язане формування деяких професійних компетенцій у сфері планування навчанням, визначення перспектив власного професійного зростання, а саме: адекватного сприйняття і оцінки своїх взаємин з учасниками освітнього процесу, вміння аналізувати результати своїх дій, прагнення до самовдосконалення (Волошина О., 2014).

Розглянувши складові педагогічної майстерності, ми виокремили наступні критерії визначення рівня сформованості педагогічної майстерності майбутнього вчителя:

- мотиваційний, який спрямований на виявлення намірів студентів до реалізації педагогічної діяльності (відображае готовність до формування професійної компетентності, прагнення до отримання спеціальних знань та формування необхідних практичних навичок, які сприятимуть професійній діяльності в майбутньому);

- когнітивний, який передбачае володіння професійно-значущими знаннями: спеціальними, психологічними, управлінськими, науково-методичними, предметними, технологічними, знаннями сощіокультурного контексту, що відображають правила й соціальні норми, етикет, традиції, культуру комунікативної поведінки, знання стратегій, які застосовуються в різних ситуаціях; стратегічні вміння (ідентифікувати й аналізувати непорозуміння в процесі спілкування), уникати непорозумінь у груповому спілкуванні й пояснювати причини їх виникнення, застосовувати вербальні та невербальні комунікативні стратегії для компенсації прогалин у знаннях і вміннях, усувати комунікативні перешкоди, отримувати нові знання й оперувати ними;

- бункціональний критерій спрямований на формування вмінь володіти технологіями реалізації професійних функцій, виконувати типові та нестандартні педагогічні завдання в професійній діяльності, приймати рішення; організовувати, стимулювати, аналізувати результативність діяльності; удосконалювати професійно-комунікативну фрункцію, формувати учнівський колектив; визначати ефективність професійної діяльності.

Висновки / Conclusions. Виокремлені компоненти та критерії сформованості педагогічної майстерності лягли в основу визначення рівнів сформованості педагогічної майстерності майбутніх учителів, що допоможе ефективно організувати освітній процес в контексті формування 
професіоналізму майбутніх педагогів. Виділення рівнів сформованості професійної майстерності майбутнього вчителя дозволило виокремити рівневі групи студентів, що дозволило більш ефективно організувати роботу з формування у майбутніх педагогів досліджуваної якості.

\section{Список використаних джерел і літератури:}

Волошина, О. В. (2014). Роль моральних відносин між учителем і учнями в навчально-виховному процесі. Наукові записки Вінницького державного педагогічного університету імені Михайла Коцюбинського, 41, 66-70 [in Ukrainian].

Громкова, М. Т. (2003). Психология и педагогика профессиональной деятельности: учеб. пособие для вузов. Москва: ЮНИТИ-ДАНА [in Russian].
Джига, Н. Д.
(2009).
Рефблексия
образование.
Взято
$\mathrm{c}:$ http://www.hetoday.org/arxiv/VOS/7_2009/38_43.pdf [in Russian]

Ефремов, О. Ю. (2010). Педагогика: учеб. пособие. Санкт-Петербург: Питер [in Russian].

Коломинский, Я. Л. (2010). Социальная психология взаилоотношений в мальх группах: учеб. пособие для психологов, педагогов, социологов. Москва: АCT [in Russian].

Роджерс, К. (1994). Взгляд на психотерапию. Становление человека. Москва: Прогресс [in Russian].

Сарджвеладзе, Н. И. (1989). Личность и ее взаилодействие с социальной средой. Тбилиси: Мецниереба [in Russian].

Харламов, И. Ф. (2004). Педагогика: учеб. пособие. Москва: Гардарики [in Russian].

\section{References:}

Voloshyna, O. V. (2014). Rol moralnykh vidnosyn mizh uchytelem i uchniamy v navchalno-vykhovnomu protsesi [The Role of Moral Adversaries between Teachers and Scholars in the Initial Process]. Naukovi zapysky Vinnytskoho derzhavnoho pedahohichnoho universytetu imeni Mykhaila Kotsiubynskoho - Scientific Notes of Vinnytsia Mykhailo Kotsiubynskyi State Pedagogical University, 41, 66-70 [in Ukrainian].

Hromkova, M. T. (2003). Psixologiya i pedagogika professional'noj deyatelnosti [Psychology and Pedagogy of Professional Activity]. Moscow: YuNITI-DANA [in Russian].

Dzhiga, N. D. (2009). Refleksiya $i$ obrazovanie [Reflection and Education]. Retrieved from: http://www.hetoday.org/arxiv/VOS/7_2009/38_43.pdf [in Russian].

Efremov, O. Yu. (2010). Pedagogika [Pedagogy]. Saint-Petersburg: Piter [in Russian].

Kolominskij, Ya. L. (2010). Social'naya psyxologiya vzaimootnoshenij v maly'x gruppax [Social Psychology of Relationships in Small Groups]. Moscow: AST [in Russian].

Rodzhers, K. (1994). Vzgliad na psixoterapiyu. Stanovlenie cheloveka [A Look at Psychotherapy. Becoming a Man]. Moscow: Progress [in Russian].

Sardzhveladze, N. Y. (1989). Lichnost $i$ ee vzaimodejstvie s socialnoj sredoj [Personality and Its Interaction with the Social Environment]. Tbilisi: Mecniereba [in Russian].

Xarlamov, Y. F. (2004). Pedagogika [Pedagogy]. Moscow: Gardariki [in Russian].

Дата надходження статті: «09» вересня 2020 р.

Стаття прийнята до друку: «20» жовтня 2020 р.

Волошина Оксана - доцент кафедри педагогіки та професійної освіти Вінницького державного педагогічного університету імені Михайла Коцюбинського, кандидат педагогічних наук, доцент

Voloshina Oksana - Assistant Professor of the Department of Pedagogy and Professional Education of Vinnytsia Mykhailo Kotsiubynskyi State Pedagogical University, Candidate of Pedagogical Sciences, Associate Professor

\section{Цитуйте иљю статтю як:}

Волошина, О. (2020). Компонентна структура, критерії сформованості професійної майстерності майбутніх педагогів. Педагогічний дискурс, 29, 1923. doi: 10.31475/ped.dys.2020.29.03.

\section{Cite this article as:}

Voloshina, O. (2020). Component Structure, Criteria, Levels of Formation of Professional Skills of Future Teachers. Pedagogical Discourse, 29, 19-23. doi: 10.31475/ped.dys.2020.29.03. 